\title{
Aloe Vera Jel İçeceği ile Zenginleştilmiş Probiyotik Yoğurt Üretimi
}

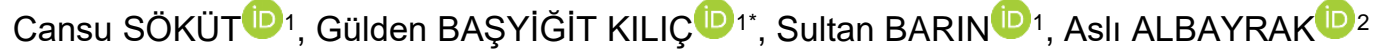 \\ ${ }^{1}$ Burdur Mehmet Akif Ersoy Üniversitesi, Mühendislik Mimarlık Fakültesi, Burdur \\ Geliş Tarihi (Received): 23.05.2021, Kabul Tarihi (Accepted): 28.06.2021 \\ $\square$ Sorumlu Yazar (Corresponding author*): gkilic@mehmetakif.edu.tr \\ (C) +902482132724 営 +902482132704
}

${ }^{2}$ Burdur Mehmet Akif Ersoy Üniversitesi, Tarım Hayvancılık ve Gıda Araştırmaları Uygulama ve Araştırma Merkezi, Burdur

\section{ÖZ}

Aloe vera (AV) süt, dondurma, şekerleme, sağlık içecekler gibi fonksiyonel gıdalarda kullanılmaktadır. Yapılan bu araştırmada, yoğurt kültürüne probiyotik ve teknolojik özelliklere sahip olan Lactobacillus plantarum AB6-25 suşu, $\% 1,2,5$ ve 5 oranlarında AV jel içeceği ilave edilerek yoğurt üretimi yapılmıştır. Depolamanın 1, 7, 14 ve 21. günlerinde üretilen yoğurtların fizikokimyasal, mikrobiyolojik analizleri ve duyusal değerlendirilmesi yapılmıştır. Analiz sonuçlarına göre; 1.ve 21. günlerde $\mathrm{pH}$ değerleri 4,54-4,61 ve 4,34-4,45, yağ değerleri $\% 2,90-3,0$ ve \%2,85-30, laktik asit cinsinden titrasyon asitliği \%0,51-0,58 ve \%1,07-1,51, kuru madde \%11,32-11,93 ve \%10,97-11,47, serum ayrılması \%24,67-39,70 ve \%29,60-39,11 arasında belirlenmiştir. Araştırma sonucunda tüm gruplar için en yüksek laktik asit bakteri sayımları 21. günde tespit edilmiştir. Duyusal özellik puanlarına bağlı olarak, AV ile üretilen yoğurtlarda 14 gün depolamanın uygun olduğu belirlenmiştir. Fizikokimyasal analiz sonuçları genel olarak değerlendirildiğinde probiyotik yoğurda AV jeli suyu ilavesi ile yoğurdun probiyotik bakteriler için taşıyıcı olarak kullanılabileceği ve \%1 ile 5 arasında AV jeli suyu ilavesinin probiyotik yoğurt üretiminde başarıyla kullanılabileceği ortaya konmuştur.

Anahtar Kelimeler: Aloe vera jel, fermantasyon, fizikokimyasal özellikler, fonksiyonel gıda

\section{Production of Probiotic Yogurt Enriched with Aloe Vera Gel Drink}

\begin{abstract}
Aloe vera $(\mathrm{AV})$ is used in functional food products including milk, ice cream, confectionery and health drinks. In this study, yogurt was produced by addition of Lactobacillus plantarum AB6-25 strain which has probiotic and technological properties, and AV gel drink at the rates of $1,2.5$ and $5 \%$. Physicochemical, microbiological analysis and sensory evaluation of yoghurts were performed produced on the $1^{\text {st }}, 7^{\text {th }}, 14^{\text {th }}$ and $21^{\text {st }}$ days of storage. Results indicated that $\mathrm{pH}$, fat, titratable acidity, dry matter and syneresis were determined as $4.54-4.61$ and, $2.90-3.0 \%$ and $0.51-0.58 \%$ and $11.32-11.93 \%$ and, $24.67-39.70 \%$ and $29.60-39.11 \%$ on day 1 and $4.34-4.45,2.85-3.0 \%, 1.07-1.51 \%, 10.97-11.47$, 24.67-39.70 and 29.60-39.11 on day 21, respectively. As a result of the research, the highest lactic acid bacteria counts for all groups were detected after 21 days of storage. Sensory analysis results revealed that 14 days of storage was the most appropriate storage period for yoghurts produced with AV. Results of the physicochemical analysis, revealed that the addition of $A V$ gel water in probiotic yoghurt could be used as a carrier for probiotic bacteria and the addition of $\mathrm{AV}$ gel water between 1 and $5 \%$ could be used successfully in the production of probiotic yoghurt.
\end{abstract}

Keywords: Aloe vera gel, fermentation, physicochemical properties, functional food 


\section{GíRiş}

Laktik asit bakterileri (LAB); fermantasyon sonucunda ürettikleri laktik asit ve diğer metabolitler ile mikrobiyal güvenliği sağlama, daha iyi organoleptik özelliklerin oluşumunu gerçekleştirme gibi teknolojik anlamda faydaları ile besin değerini arttırıcı ve probiyotik özellik göstermesi gibi avantajlarıyla önem taşımaktadır. Yapılan farklı araştırmalarda; çeşitli LAB'nin patojenik mikroorganizmaları inhibe etme özellikleri, probiyotik özellikleri ve farklı kaynaklardan elde edilen LAB suşlarının antimikrobiyal aktiviteleri araştırılmıştır (Todorov, 2009; Başyiğit, 2004; Başyiğit Kılıç ve ark., 2013; Başyiğit Kılıç ve Akpınar, 2013. Mokoena, 2017). Bu bakterilerin endüstriyel ve sağlık alanında kullanımlarına yönelik araştırmalar oldukça fazladır (Başyiğit Kılıç ve ark., 2006; Başyiğit Kılıç ve ark., 2009; Xiong ve ark., 2012; Kaya, 2013; Başyiğit Kılıç ve Akpınar, 2016). Endüstriyel üretimde kullanılan birçok gıda katkı maddesinin bazı sağlık ve çevre sorunlarına sebep olduğu gerekçesiyle, tüketicilerin doğal gıda katkı maddelerinin kullanılmasına ilgisi artmaktadır. Sağlığa yararlı birçok fonksiyonel özelliklerinden dolayı probiyotiklerin doğal gıda katkı maddesi olarak kullanımı giderek artmaktadır (Uymaz, 2010). Probiyotikler, belirli oranda tüketildiğinde tüketici sağlığını destekleyici, immün sistemi uyaran canlı mikrobiyal kültürler olarak tanımlanmaktadır. Son yıllarda yapılan çalışmalarda fonksiyonel bileşenler arasında önemli yeri olan probiyotiklerin gıdalarda ve metabolizmada toksik bileşenlerin parçalanmasında etkili olduğu, genel anlamda sağlık durumunda da iyileşmeler gösterdiği, hamile bireylerde probiyotik alımının bebeğin bağırsak florasına, yetişkin bireylerde ise vücut ağırlığının dengelenmesinde katkıda bulunduğu ve bu sebeplerden dolayı probiyotiklerin düzenli tüketilmesi gerektiği belirtilmektedir (Omak ve ark., 2016). Ancak her probiyotik aynı etkiyi göstermemektedir. Probiyotik özellik gösteren mikroorganizmaların fizyolojik farklılıkları, beslenme davranışları ve yaşadıkları ortamın farklı olması gibi nedenlere bağlı olarak etki mekanizması da farklııklar gösterebilir (Işıdan, 2009). Günümüzde birçok süt ürününde Lactobacillus acidophilus, Lactobacillus paracasei ve Bifidobacterium türleri yaygın olarak kullanılmaktadır. Bu bakterilerin sağlık açısından olumlu etkilere sahip olan suşlarının gün geçtikçe dondurma, yoğurt, fermente süt gibi ürünlerde kullanımları artmaktadır (Çelikel ve ark., 2018). Fermente süt ürünlerinin probiyotik mikroorganizmaları taşıyabilecek en iyi gıda ürünleri olduğu bildirilmiştir. Ancak fermente süt ürünlerinde kullanılan probiyotik mikroorganizmaların sağlık üzerine olumlu etki gösterebilmeleri için, belli sayıda mikroorganizma içermeleri ve bu mikroorganizmaların ürün tüketilene kadar canlılığını ve stabilitesini sürdü- rebilmesi gerekmektedir. Probiyotik bakterilerin canlılıklarını koruma oranları türler arasında farklılık gösterir. Bu sebeple fermente ürünlerde probiyotik mikroorganizma kullanımında farklı türlerin kombinasyonlarının kullanılması ve uygun kültürlerin seçilmesi gerekmektedir (Yılmaz, 2006).

Aloe vera (AV) binlerce yıldır çeşitli kültürlerde farklı hastalık ve cilt sorunlarının tedavi edilmesi gibi amaçlar için kullanılan çok yıllık şifalı bir bitkidir. Mısırılar bu bitkiye 'ölümsüzlük bitkisi 'adını vermişlerdir. AV'nin bilinen 275 'ten fazla türü vardır. Bunlardan yalnızca 4 tanesi ticari kullanıma uygundur. Aloe barbadensis miller tıbbi açıdan aralarında en fazla kullanılanıdır. Aloe arborescens, Aloe dichotoma ve Aloe nyeriensis şifalı olan diğer üç türüdür (Çete, 2005). AV bitkisi potansiyel olarak aktif 70'den fazla bileşen içerir: Ayrıca AV'nin insan sağlığı üzerine birçok olumlu etkisi vardır. Bağışıklık sistemi üzerine olumlu etkileri, antiviral ve antitümör aktivitesi, antioksidan, nemlendirici ve yaşlanma karşıtı etkileri, antiseptik etkileri bunlardan bazılarıdır (Surjushe ve ark., 2008). AV'nin yapısında bol miktarda A vitamini, C, E, B12 vitamini, kolin ve folik asit bulundurur (Deveci ve ark., 2016). Yapılan bazı in vitro çalışmalar sonucunda AV'nin insan karaciğerindeki kanser hücrelerinde antiproliferatif etkisinin olduğu da görülmüştür (Tekin ve ark., 2006). Sentetik antioksidanlar, sağlık açısından önemli riskler içermektedir. Bazı ülkelerde sentetik antioksidanların gıdalarda kullanımı, kanser riski olabileceği şüphesiyle yasaklanmış veya sınırlandırılmıştır. Bu sebeplerden dolayı sentetik antioksidanların yerini doğal antioksidanlar almaya başlamıştır ve doğal antioksidanlara verilen önem giderek artmaktadır. AV önemli bir antioksidan olup, gıdalarda kullanımı uygundur (Oğan ve Sezgin, 2019). Bitki materyali olarak bilinen AV; jel ve meyve suyu şeklinde işlenerek, gıda ve kozmetik ürünlerde temel bileşen olarak kullanılmaktadır. AV yapısında çeşitli şekerler içermektedir. En aktif şeker bileşeni ise mannoz polimeri olan acemannan maddesidir (Javed, 2014). AV'nin birey sağlığına katkısı yaprakların jelinde bulunan polissakkaritler sayesinde gerçekleşmektedir. Yapraklarında bulunan jelin son zamanlarda keşfedilen etkileri sonucunda yaprak üzerine uygulama çalışmaları artmıştır (Hamman, 2008).

Yeni probiyotik formülasyonlarının geliştirilmesine duyulan ilgi; gıda ve nutrasötik endüstrisini ve buna bağlı olarak tüketicilerinin genel sağlık ve refahını desteklemektedir. AV besin değeri yüksek gıda katkı maddesi olarak; gıdaların kalitesini arttırmak ve raf ömrünü uzatmak amacıyla kullanılmaktadır. AV'nin doğal bir ürün olması sebebiyle gıda endüstrisinde zararsız katkı maddesi olarak kullanımı gittikçe yaygınlaşmak- 
tadır. Son yıllarda AV suyu, jeli ve pulpunun meyve suları, çaylar, çeşitli sütlü tatıllar, yoğurtlar ve farklı et ürünleri gibi gıda ürünlerinin formülasyonlarında da kullanımına yönelik çalışmaların arttığı görülmektedir. (Panesar ve Shinde, 2012; Başyiğit Kılıç ve ark., 2020). AV ilavesi ile hazırlanan süt ürünlerinin popülerliği gün geçtikçe artmaktadır. AV suyu ile hazırlanan yoğurdun, yağsız süt tozu kullanarak hazırlanan yoğurda kıyasla daha iyi bir kaliteye sahip olduğu yapılan çalışmalar sonucu doğrulanmıştır (Kaur ve ark., 2015; Yadav ve ark., 2018). Niko ve ark. (2016) tarafından yapılan çalışmada, L. casei ve AV jel sulu ekstraktın süt ürünlerinde doğal koruyucu madde olarak kullanılabileceği sonucuna varılmıştır. AV suyunun veya jelinin probiyotik gıdalarda kullanımının süt ürünlerinin fonksiyonel bileşeninin artırılmasına destek sağlayacağı belirtilmektedir. Yapılan bu araştırmada, insan sindirim sisteminden izole edilmiş, probiyotik ve teknolojik özellikleri araştırımış olan L. plantarum AB6-25 suşu ile şeftalili AV jel içeceği ile yoğurt üretiminin optimizasyonu yapılmıştır. Çalışmada seçilmiş olan suşun, yoğurt üretimindeki canlılığı, farklı miktarlardaki AV jel içeceğinin kültürün canlılığı üzerindeki ve yoğurttaki fizikokimyasal etkisi ayrıntılı şekilde araştırılmıştır.

\section{MATERYAL VE YÖNTEM}

Çalışmada yoğurt üretimi kontrol ve deneme grupları olmak üzere gerçekleştirilmiştir. Üretimde probiyotik kültür olarak; teknolojik ve probiyotik açıdan en üstün özellikleri belirlenmiş olan L. plantarum AB6-25 suşu kullanılmıştır (Başyiğit, 2004; Başyiğit Kılıç ve Karahan, 2010; Başyiğit Kılıç ve ark., 2013). Şekersiz, \%98 yaprak jelli şeftalili AV içeceği LR (Almanya) firmasından, yoğurt üretiminde kullanılan işletme kültürü MAKÜ Süt Teknolojileri Araştırma ve Geliştirme Merkezi Laboratuvarı'ndan temin edilmiştir.

\section{Kültürün Hazırlanması}

Üretimde kullanılan Lactobacillus plantarum AB6-25 suşu MRS SIVı besiyerinde son üründe $10^{7}-10^{8}$ $\mathrm{KOB} / \mathrm{ml}$ olacak şekilde geliştirilmiş ve steril $1 / 4$ ringer çözeltisi ile yıkanmıştır. Elde edilen kültür peleti üretimde kullanılacak süt ile çözündürüldükten sonra üretimde kullanılan süte aşılanmıştır (Başyiğit ve ark., 2006).

\section{Yoğurt Üretimi}

Yoğurt üretimi Mehmet Akif Ersoy Üniversitesi, Mühendislik Mimarlık Fakültesi, Gıda Mühendisliği Bölümü'ne ait laboratuvarda gerçekleştirilmiştir. Üretimde kullanı- lan pastörize ve homojenize süt su banyosunda aşılama sıcaklığı olan $44^{\circ} \mathrm{C}$ 'ye ısıtılmıştır.

Üretilen gruplar aşağıda belirtilmiştir.

Kontrol grubu $(\mathrm{K}) \quad$ : İşletme kültürü $(\% 2)$

Deneme grubu 1 (D1) : İşletme kültürü $(\% 1)+$ L. plantarum AB6-25 (\%1)

Deneme grubu 2 (D2) : İşletme kültürü (\%1) + L. plantarum AB6-25 (\%1) + \%1 Aloe vera içeceği

Deneme grubu 3 (D3) : İşletme kültürü (\%1) + L. plantarum AB6-25 (\%1) + \%2,5 Aloe vera içeceği

Deneme grubu 4 (D4) : İşletme kültürü (\%1) + L. plantarum AB6-25 (\%1) + \%5 Aloe vera içeceği

Hazırlanan sütler 100 ml'lik steril cam şişelere dağıtılıp $42^{\circ} \mathrm{C}$ 'de pH'sı 4.6'ya ulaşana kadar inkübe edilmiştir. Inkübasyondan sonra $4^{\circ} \mathrm{C}$ 'ye soğutulup 3 hafta süre ile bu sıcaklıkta depolanmıştır. Depolamanın 1, 7, 14 ve 21. günlerinde fizikokimyasal, mikrobiyolojik analizleri ve duyusal değerlendirilmesi yapılmıştır (Üçüncü, 2005).

\section{Yoğurtların Mikrobiyolojik Analizleri}

Tüm mikrobiyolojik analizler için için steril $1 / 4$ ringer çözeltisi kullanılarak yoğurt örneklerinden seri dilüsyonlar hazırlanarak uygun dilüsyonlardan besiyerlerine ekim yapılmıştır. Yoğurt örneklerinin toplam LAB sayısını belirlemek için de Man, Rogosa and Sharpe (MRS) agar kullanılmış, Petri kutuları $37^{\circ} \mathrm{C}$ 'de 48 saat inkübe edilmiştir. Toplam mezofilik aerob bakteri (TMAB) sayısı Plate Count Agar (PCA) (Merck) besiyeri kullanılarak $30^{\circ} \mathrm{C}$ 'de 48 saat inkübasyonla belirlenmiştir. Toplam koliform bakteri sayısı Eosin Metilen Blue Agar (EMB) (Merck), maya ve küf sayısı ise Potato Dekstroz Agar (PDA) (Merck)'da belirlenmiştir. EMB besiyeri $37^{\circ} \mathrm{C}$ 'de 48 saat, $\mathrm{PDA}$ besiyeri ise $25^{\circ} \mathrm{C}$ 'de 5 gün süre ile inkübe edilmiştir (Özçelik, 1998; Karahan ve ark., 2002; Halkman, 2005).

\section{Yoğurtların Fizikokimyasal Analizleri}

Kuru madde tayini için önceden etüvde kurutulup tartımı alınan ve içerisinde deniz kumu bulunan kurutma kapları içerisine yaklaşık 2-3 g olacak şekilde yoğurt örneği tartılarak $105 \pm 2^{\circ} \mathrm{C}$ 'de sabit ağırlığa gelene kadar kurutulmuştur. Kurutma öncesi ve sonrası alınan tartımlara göre örneklerin kuru madde miktarları \% olarak hesaplanmıştır (Anonim, 2006). Yoğurtların yağ içeriği Gerber yöntemi ile, titre edilebilir asitliği (TA) Anonim (2006)'e göre belirlenmiştir.

Serum ayrılmasının belirlenmesi için tartılan $20 \mathrm{~g}$ yo- 
ğurt örneği 640 g'de $4^{\circ} \mathrm{C}$ 'de 10 dakika süre ile santrifüjlenmiştir. Santrifüjleme işlemi sonrasında elde edilen supernatant tartılarak Keogh ve O'Kennedy (1998)'ye göre \% serum ayrılması miktarları belirlenmiştir.

Yoğurtların duyusal değerlendirilmesi, depolamanın 1., 7., 14. ve 21. günlerinde yoğurdun aroması, tadı ve yapısı konusunda bilgi sahibi, eğitilmiş 6 kişi tarafından TS 1330 Yoğurt Standardı'nda önerilen puanlama sistemi ve parametreler kullanılarak gerçekleştirilmiştir (Anonim, 2006). Değerlendirme için panelistlere yoğurt örneklerinin görünüş, kıvam, tat ve kokusu ile ilgili sorular yöneltilmiştir.

\section{İstatistiksel Analizler}

Araştırma 2 tekerrürlü ve analizler 2 paralelli olacak şekilde gerçekleştirilmiştir. Analizler sonucunda gruplar arasındaki farklılıklar SPSS 25 programında tek yönlü varyans analizi (ANOVA) tekniği ile tespit edilmiştir. İstatistiksel olarak önemli bulunan gruplar ve depolama günleri arasındaki farklııklar ise Duncan testi kullanılarak belirlenmiştir. İstatistiksel anlamlılık \%95 güven düzeyinde tespit edilmiş $(p<0.05)$ ve sonuçlar, standart sapma ile birlikte verilmiştir ( \pm standart sapma).

\section{BULGULAR VE TARTIŞMA}

Yapılan araştırmada örneklerin depolama süresi boyunca mikrobiyolojik, fizikokimyasal ve duyusal analiz sonuçları Tablo 1, 2 ve 3'te verilmiştir. Üretilen yoğurtların $\mathrm{LAB}$, küf, maya, koliform ve TMAB sayılarını belirlemek amacıyla K, D1, D2, D3 ve D4 grupları uygun besiyerlerine ekim yapılarak; 1, 7, 14 ve 21. günlerdeki bakteri sayımları yapılmıştır. Bu sayım sonuçlarına göre tüm günlerde ve tüm gruplarda koliform ve küf maya sayısı $<10$ olarak bulunmuştur. LAB sayısı K grubunda günler arasında giderek artmış, tüm gruplar için en yüksek sayımlar 21. günde bulunmuştur ancak LAB sayım sonuçlarında $K, D 1, D 3$ ve D4 gruplarında 1.ve 21. gün sayılarında fark tespit edilmemiştir. Sadece D2 grubunun 1 ve 21. günü kıyaslandığında 21. gündeki artış önemli düzeyde $(p<0,05)$ farklı bulunmuştur. Tüm gruplar arasında 7 . ve 21. günde $T M A B$ sayısında farklılık tespit edilmezken, 1. gün D4 grubu TMAB sayısı anlamlı düzeyde $(p<0,05)$ yüksek bulunmuştur. K, D1, D2 ve D3 gruplarında TMAB sayısı açısından depolama süresince farklılık tespit edilmezken, D4 grubunda TMAB sayısı 7. günden itibaren anlamlı düzeyde $(p<0.05)$ azalmıştır. Muhtekar ve ark. (2018) $\% 12,14-16,18$ AV ilave edilmiş yoğurtta TMAB sayısını $5,75 \times 10^{7} \mathrm{KOB} / \mathrm{ml}$, küf, maya, koliform sayısını ise 0 olarak belirlemişlerdir.

Tablo 1. Depolama süresince yoğurtların mikrobiyolojik analiz sonuçları

\begin{tabular}{lcccc}
\hline GRUPLAR & 1. Gün & 7. Gün & 14. Gün & 21. Gün \\
\hline LAB & $7.44 \pm 0.12^{\mathrm{aA}}$ & $7.21 \pm 0.59^{\mathrm{abA}}$ & $7.44 \pm 0.45^{\mathrm{aA}}$ & $7.68 \pm 0.65^{\mathrm{aA}}$ \\
K & $7.42 \pm 0.29^{\mathrm{aAB}}$ & $6.62 \pm 0.04^{\mathrm{bB}}$ & $7.69 \pm 0.12^{\mathrm{aAB}}$ & $7.87 \pm 0.44^{\mathrm{aA}}$ \\
D1 & $7.41 \pm 0.40^{\mathrm{aB}}$ & $7.13 \pm 0.52^{\mathrm{abB}}$ & $7.45 \pm 0.01^{\mathrm{aB}}$ & $7.89 \pm 0.48^{\mathrm{aA}}$ \\
D2 & $7.58 \pm 0.30^{\mathrm{aAB}}$ & $7.30 \pm 0.09^{\mathrm{aB}}$ & $7.46 \pm 0.10^{\mathrm{aAB}}$ & $7.81 \pm 0.44^{\mathrm{aA}}$ \\
D3 & $7.72 \pm 0.43^{\mathrm{aAB}}$ & $6.97 \pm 0.35^{\mathrm{abB}}$ & $7.52 \pm 0.03^{\mathrm{aAB}}$ & $7.80 \pm 0.29^{\mathrm{aA}}$ \\
D4 & $7.53 \pm 0.76^{\mathrm{bA}}$ & $7.69 \pm 0.20^{\mathrm{aA}}$ & $7.20 \pm 0.02^{\mathrm{bA}}$ & $7.83 \pm 0.60^{\mathrm{aA}}$ \\
TMAB & $8.15 \pm 0.43^{\mathrm{bA}}$ & $7.87 \pm 0.19^{\mathrm{aA}}$ & $7.52 \pm 0.16^{\mathrm{abA}}$ & $8.02 \pm 0.42^{\mathrm{aA}}$ \\
K & $8.07 \pm 0.35^{\mathrm{bA}}$ & $7.95 \pm 0.10^{\mathrm{aA}}$ & $7.63 \pm 0.07^{\mathrm{aA}}$ & $8.01 \pm 0.36^{\mathrm{aA}}$ \\
D1 & $8.13 \pm 0.51^{\mathrm{bA}}$ & $7.81 \pm 0.28^{\mathrm{aA}}$ & $7.59 \pm 0.02^{\mathrm{aA}}$ & $7.98 \pm 0.43^{\mathrm{aA}}$ \\
D2 & $8.85 \pm 0.11^{\mathrm{aA}}$ & $7.90 \pm 0.01^{\mathrm{aB}}$ & $7.75 \pm 0.18^{\mathrm{aB}}$ & $8.12 \pm 0.29^{\mathrm{aB}}$ \\
D3 & & &
\end{tabular}

$a-b(\downarrow)$ Test edilen her parametre için (LAB, TMAB) aynı sütunda aynı harfleri taşıyan ortalamalar arasındaki fark istatistiksel olarak önemli değildir $(p>0.05)$.

$\mathrm{A}-\mathrm{B}(\rightarrow)$ Test edilen her parametre için (LAB, TMAB) aynı harfleri taşıyan ortalamalar arasındaki fark istatistiksel olarak önemli değildir ( $p>0.05)$.

Yeganehzad ve ark. (2007) tarafından yapılan çalışmada toplam \%8.5 kuru madde içeren yağsız süt vakum evaparatörü ile toplam \%15 ve 20'ye konsantre edilmiş ve probiyotik L. acidophilus ile aşılanmıştır. Yoğurtlar 42 ${ }^{\circ} \mathrm{C}$ 'de inkübe edilmiş ve $4{ }^{\circ} \mathrm{C}$ 'de depolanmıştır. Laktoba- 
sillerin canlıı̆̆ı, $\mathrm{pH}$, asitlik, sineresiz ve sertlik gibi fizyokimyasal, tat ve tekstür gibi duyusal özelikler probiyotik yoğurtlarda 7, 14 ve 21. günlerde analiz edilmiştir. Sütte artan toplam kurumadde miktarı L. acidophilus'un canlılığını ve yoğurdun asitliğini arttırırken, $\mathrm{pH}$ ve sinerezisi azaltmıştır. Ancak L. acidophilus'un canlılığı $4{ }^{\circ} \mathrm{C}$ 'de depolama süresince azalmıştır. Yapılan araştırmamızda 21. günde $D$ gruplarında $L A B$ ve $L$. plantarum sayım sonuçları $\mathrm{K}$ grubundan yüksek bulunsa da, bu fark istatistiki olarak önemli bulunmamıştır. Hussain ve ark. (2015) Aloe barbadensis miller suyu ve probiyotik Lactobacillus paracasei ssp. paracasei ilave edilmiş lassi'nin; ürünün duyusal kalitesi, $\mathrm{pH}$ ve probiyotik sayısı üzerine depolamanın etkisini incelemişlerdir. $5 \pm 1^{\circ} \mathrm{C}$ 'de depolanan AV destekli probiyotik lassi'nin 12 gün boyunca depolama süresince probiyotik sayımları ilk gün $8.4 \mathrm{log} \mathrm{KOB} / \mathrm{mL}$ iken 12. gün $8.0 \log \mathrm{KOB} / \mathrm{mL}$ 'ye düşmüştür. Mahmoudi ve ark. (2016) tarafından yapılan araştırmada; inek sütü, $\% 2.5$ ve \%5 AV özü ve L. casei (ATCC 3939) ilave edilen yoğurtların depolamanın $1,3,5,7$ ve 10 günlerinde fizikokimyasal, mikrobiyolojik ve duyusal özellikleri araştırılmıştır. L. casei'nin canlılığı, depolama süresi sonrasında AV ekstraktlı olan probiyotik yoğurtta, diğer probiyotik yoğurtlara oranla daha yüksek bulunmuştur. Bu araştırmada ise AV ilaveli probiyotik yoğurtlarda ise 21. günde en yüksek $L A B$ sayım sonucu D2 grubunda tespit edilmiştir. Yadav ve ark. (2018) ise, aromalı AV küpleri probiyotik yoğurttaki meyve jölesi küpleri yerine kullanılmıştır. AV'li probiyotik yoğurt, probiyotik L. acidophilus (NCIM2903) ve yoğurt kültürleri ile beraber $37^{\circ} \mathrm{C}$ 'de 24 saat inkübe edilmiştir. AV'li probiyotik yoğurt AV küplerinin ananas ve litchi suyuna emdirilmesiyle standardize süt kullanılarak üretilmiştir. İnkübasyon $42^{\circ} \mathrm{C}$ 'de 4,30 saat süreyle yapılmış, yoğurtlar 14 gün depolanmıştır. MRS besiyerinde yapılan LAB sayımı 0 . gün $9.1 \times 10^{7}-7.4$ $\times 10^{7}, 7$. günde $8.8 \times 10^{7}-6.32 \times 10^{7}, 14$. gün $8.55 \times 10^{7}$ $6.15 \times 10^{7}$, maya ve küf sayısı sırasıyla $15-45$ arasında bulunmuştur. 14 günlük depolama sonunda probiyotik yoğurt sayım sonuçları $10^{6} \mathrm{KOB} / \mathrm{ml}$ 'nin üzerinde tespit edilmiştir ve bu üründe yararlı mikroorganizmalar daha iyi canlılık göstermiştir. Karami (2018), çinko, B12 vitamini, kekik ve AV özleri ile birlikte hazırladıkları İran yoğurt içeceğinde $L$. acidophilus LA-5'in canlılığını araştırmışlardır. 1.9 mg/L B12 vitamini ve $17.6 \mathrm{mg} / \mathrm{L}$ çinko ilavesinin, probiyotik suşun sayısını arttırdığı ve çinkonun etkisinin B12 vitamininden daha fazla olduğu, probiyotik suşun logaritmik bakteri sayısının kekik ve $10 \mathrm{mg} / \mathrm{L}$ AV özü ilavesiyle arttığı, çinko ve AV özünün birlikte kullanılmasıyla en yüksek probiyotik bakteri sayısına ulaşıldığı tespit edilmiştir. Karami ve Khodakarami (2019) tarafından yapılan araştırmada ise; \%0.5, 1, 1.5 ve $2 \mathrm{w} / \mathrm{w}$ $A V$ özü ile ürettikleri az yağlı probiyotik yoğurtta AV özünün ilavesiyle Bifidobacterium ve Lactobacillus canlılığı artarken, maya ve küf sayılarının azaldığı görülmüştür.

Üretilen yoğurdun 1, 7, 14 ve 21. günlerde K, D1, D2, D3 ve D4 gruplarında $\mathrm{pH}, \%$ yağ, \%asitlik, \%kuru madde ve $\%$ serum ayrılması analizleri yapılmıştır. $\mathrm{pH}$ analiz sonuçlarına göre; 1. günde $\mathrm{pH}$ değerlerinin 4.54-4.61, 21. günde ise 4.34-4.45 arasında olduğu belirlenmiştir. Tüm depolama günlerinde gruplar arasındaki farkın önemli olmadığı, depolama süresince gruplarda $\mathrm{pH}$ değişiminde azalış gözlemlense de sadece 21. günde D1, D3 ve D4 gruplarındaki azalmanın 1. güne kıyasla anlamlı düzeyde $(p<0.05)$ olduğu tespit edilmiştir. Grupların yağ miktarının \%2.80 ile 3.15 arasında değişim gösterdiği, ölçüm zamanı faktörünün istatistiksel olarak anlamlı bir etkisinin olmadığı belirlenmiştir. Tüm gruplarda yağ miktarının birbirine yakın olduğu, sadece 14 . günde $D 1$ 'in (\%3.15); D3 (\%2.90) $(p=0.021)$ ve D4 (\%2.80) $(p=0.001)$ gruplarından daha yüksek değerlere sahip olduğu tespit edilmiştir. Örneklerin TA sonuçları değerlendirildiğinde; başlangıç değerleri \% 0.51.ile 0.58 arasında iken, 21. günde ise $\% 1.07$ ile 1.15 arasında olduğu belirlenmiştir. Analiz günlerinde gruplar arasında farklılık tespit edilmezken, depolamanın 21. gününde tüm gruplardaki artışın 1. güne kıyasla önemli olduğu $(p<0.05)$ görülmüştür.

\% Kuru madde sonuçlarının 10.64 ile 12.69 arasında değiștiği, 1. günde D3 grubunun kuru madde miktarı (12.69) diğer gruplardan yüksek iken $(p<0.05), 21$. günde D2'nin $(11,47)$ diğer gruplardan daha yüksek değere $(p<0.05)$ sahip olduğu tespit edilmiştir. 1 ve 21 . gün sonuçları kıyaslandığında D1, D2 ve D3 gruplarındaki azalışlar önemli $(p<0.05)$ bulunmuştur. Grupların serum ayrılması miktarları \%23.93 ile 39.70 arasında tespit edilmiştir. Depolamanın 1. gününde en az serum ayrılması K grubunda (\%24.67) belirlense de, sadece D3 grubundan (\%39.70) önemli derecede $(p<0.05)$ farklı bulunmuştur. Serum ayrılması 21. günde sadece D1 grubunda (\%26.89) anlamlı düzeyde azalırken $(p<0.05)$, diğer gruplarda \%26.90 ile 39.11 arasında belirlenmiştir.

Tablo 2. Depolama süresince yoğurtların fizikokimyasal analiz sonuçları

\begin{tabular}{lllll}
\hline GRUPLAR & 1. Gün & 7. Gün & 14. Gün & 21. Gün \\
\hline
\end{tabular}


Aloe Vera Jel İçeceği İle Zenginleştilmiş Probiyotik Yoğurt Üretimi

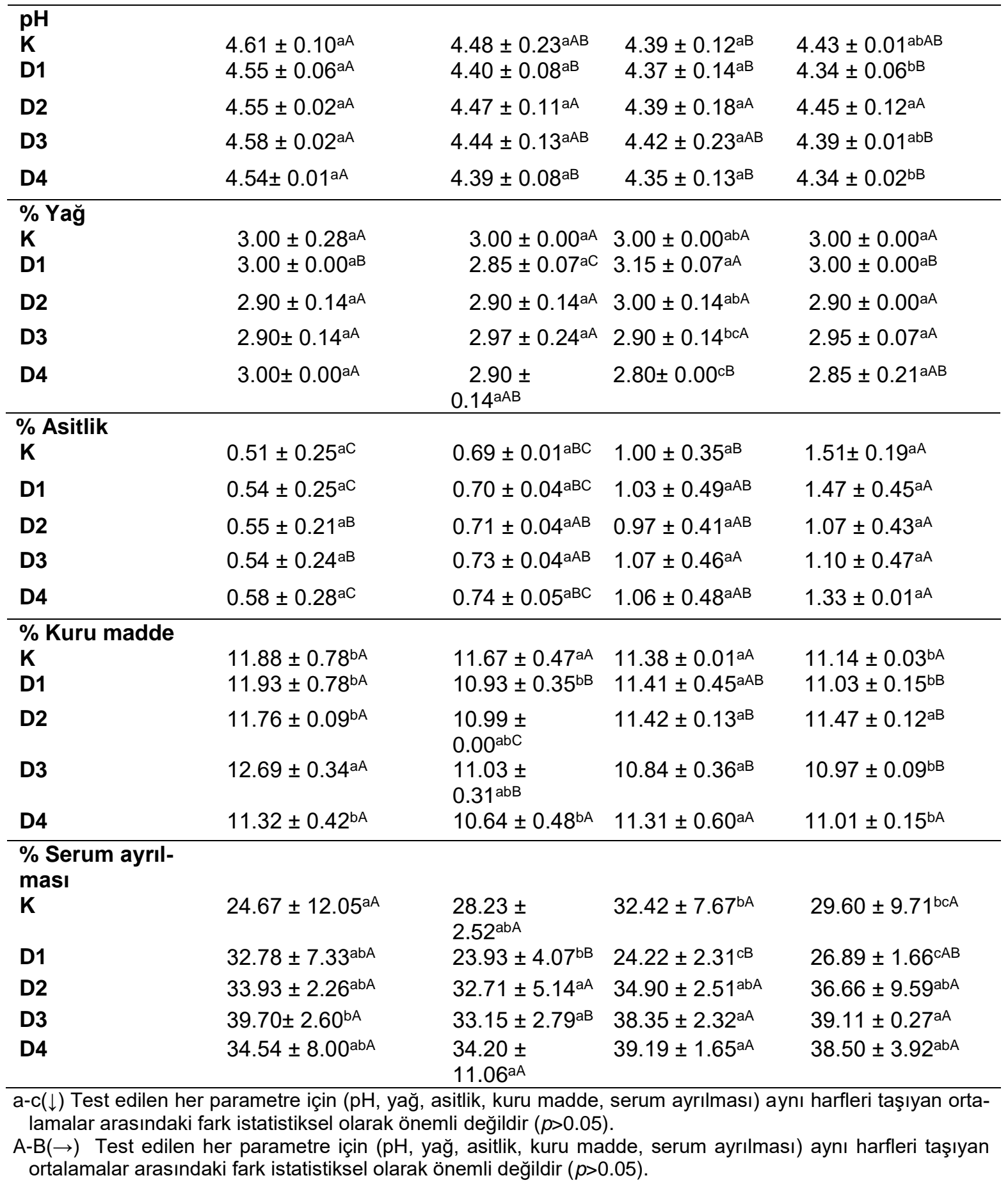

Mahmoudi ve ark. (2016)'nın araştırmasında $4^{\circ} \mathrm{C}$ 'de depolama süresi boyunca, bizim sonuçlarımızla benzer şekilde TA artmış ve pH değerleri önemli ölçüde azalmıştır $(P<0.05)$ ve yoğurtların duyusal değerlendirmesinde $A V$ ekstraktının eklendiği yoğurt örnekleri ile eklenmeyen yoğurtların duyusal kalitesi arasında fark olmadığı gözlemlenmiştir. 10 günlük depolama süresi boyunca yoğurt numunelerinin su tutma kapasitesi yüzdesi azalmış ve sinerezis yüzdeleri artmıştır $(p<0.05)$. Bizim araştırmamızda sadece D1 grubunda serum ayrılması azalırken, Mahmoudi ve ark. (2016)'ye benzer şekilde diğer gruplarda serum ayrılması artmıştır. Yadav ve ark. (2018) tarafından yapılan çalışmada ise, AV küplerinin probiyotik yoğurtta fiziksel ve kimyasal özelliklerinin incelenmesi sonucu sırasıyla maksimum ve minimum değerler; yağ \%4.78-4.7, toplam kuru madde \%28.21-27.94, toplam 
çözünür kuru madde 0 . günde \%35-31, pH 4.024-4.04, toplam titre edilebilir asitlik \%1.16-0.39 arasında belirlenmiştir. Mencia (2018)'nin \%2 yağlı süt, yoğurt kültürü, $\% 5$ ve \%15 AV suyu ve \%1.5 inülin ilave ederek hazırladıkları yoğurtlarda zaman içerisinde $\mathrm{pH}$ değerinin azaldığı ve TA değerinin arttığı gözlemlenmiştir. AV ve inülin seviyelerinin artırılması sonucunda $\mathrm{pH}$ ve TA değerleri düşmüş, depolama süresince sinerezis artmış, viskozite azalmıştır. Karami ve Khodakarami (2019)'nin araştırmasında ise, AV ekstraktının eklenmesinin; az yağlı probiyotik yoğurtta $\mathrm{pH}$ değerini düşürdüğü ve asitliği artırdığı ancak sinerezi azalttığı belirlenmiştir. El-Sayed (2020)'in AV özü ve probiyotik bakteri kullanarak ürettikleri ultra filtre-yumuşak peynirlerde; ilave edilen AV özünün yüzdesinin artmasıyla ultra filtre peynirinin toplam kuru madde, protein, $\mathrm{pH}$ ve yağ içeriği önemli ölçüde azaldığı, \%15 AV'li örneklerde, normale kıyasla probiyotik sayımlarının depolama periyodunun sonunda $1.5 \mathrm{log}$ oranında arttığı gözlemlenmiştir. Ikram ve ark. (2021) yıIında yapılan araştırmada ise, süt yağının AV jeli ile değiştirilmesi ile manda yoğurtları üretilmiştir. Araştırmada \%3.5 yağ ile üretilen kontrol grubu, \%1 yağ-\%1 AV jeli, \%1 yağ-\%2 AV jeli, \%1 yağ-\%3 AV jeli, \%2 yağ-\%1 AV jeli, \%2 yağ-\%2 AV jeli ve \%2 yağ-\%3 AV jeli içeren yoğurt grupları ile kıyaslanmıştır. Yoğurdun tüm özellikleri, AV jeli ilavesinden önemli ölçüde etkilenmiştir. Araştırma sonucunda $\mathrm{pH}$ 4.6-4.05, viskozite 46.4-4.3, yağ \%0.93.48 , toplam kuru madde $\% 11.08-17.18$ olarak belirlenmiştir. Bununla birlikte, yoğurtların asitliği ve sinerezi sırasıyla \%1.12-1.67 ve 0.9-5 ml olarak zaman geçtikçe artmıştır. Araştırma sonucunda \%1 yağ içeren yoğurda \%3 AV jeli ilavesinin fizikokimyasal ve organoleptik özellikler için en iyi olduğu sonucuna varılmıştır.
AV jel ile zenginleştirilmiş probiyotik yoğurt için yapılan duyusal analiz testi sonuçlarına göre; panelistler tarafından yoğurdun dış görünüşü, kıvamı (kaşıkla ve ağızda), ve tadı bakımından 1, 7, 14 ve 21.günlerde $K, D 1$, D2, D3 ve D4 grupları arasında istatiksel olarak anlamlı bir değişim tespit edilmemiştir. Depolamanın 14. gününde D1, D2, D3 ve D4 gruplarının koku puanları $\mathrm{K}$ grubundan anlamlı derecede $(p<0.05)$ düşük bulunmuştur. 1. ve 21 . günlerde dış görünüş puanlarının 21. günde $K, D 1, D 2$ ve D4 gruplarında, kıvam (kaşıkla) puanlarının ise D3 ve D4 gruplarında puanların anlamlı düzeyde azaldığı $(p<0.05)$ belirlenmiştir. 14. günde D1, D2, D3 ve D4 gruplarının hepsinin duyusal analiz sonuçları bakımından benzer özellikler gösterdiği söylenebilir.

Muhtekar ve ark. (2018) tarafından \%14 AV eklenmiş yoğurdun, duyusal açıdan en yüksek genel kabul edilebilirlik puanı 8.31, renk ve görünüm puanı 8.60 , lezzet 8.40 , görünüş ve yapı 8.00 , tat 8.25 , genel kabul edilebilirlik puanı 8.31 olarak belirlenmiştir. Karami ve Khodakarami (2019)'nin araştırmasında duyusal analiz sonuçlarına göre panelistlerin AV oranı düşük yoğurt örneklerini tercih ettikleri görülmüştür. Bununla birlikte, daha yüksek AV ekstraktı, lezzeti ve genel kabul edilebilirliği etkilemiş ve panelist puanlarını düşürmüştür. Zaman içinde $\mathrm{pH}$ azalıp, asitlik ve sinerez artmıştır. Genel olarak, tüm yönlerden en iyi uygulamanın \%0.5 AV ekstresi olduğu sonucuna varılmıştır. Bizim araştırmamızda ise, farklı konsantrasyonlarda AV ilavesinin depolama süresince yoğurtlarda asitlik gelişimini artırırken $(p<0.05)$, depolamanın 21. gününde gruplar arasında TA ve yoğurtların tadı üzerinde farklılık oluşturmadığı belirlenmiştir. 
Aloe Vera Jel İçeceği İle Zenginleştilmiş Probiyotik Yoğurt Üretimi

Tablo 3. Depolama süresince yoğurtların duyusal analiz sonuçları

\begin{tabular}{|c|c|c|c|c|}
\hline GRUPLAR & 1. Gün & 7. Gün & 14. Gün & 21. Gün \\
\hline \multicolumn{5}{|l|}{ Dış görünüş } \\
\hline $\mathrm{K}$ & $5.00^{\mathrm{aA}}$ & $4.33^{\mathrm{aAB}}$ & $4.67^{\mathrm{aAB}}$ & $3.33^{\mathrm{aB}}$ \\
\hline D1 & $5.00^{\mathrm{aA}}$ & $4.33^{a A}$ & $4.67^{\mathrm{aA}}$ & $2.67^{\mathrm{aB}}$ \\
\hline D2 & $5.00^{\mathrm{aA}}$ & $4.00^{\mathrm{a} A \mathrm{~B}}$ & $4.00^{\mathrm{aAB}}$ & $3.67^{\mathrm{aB}}$ \\
\hline D3 & $4.33^{\mathrm{a}}$ & $4.00^{\mathrm{aA}}$ & $4.33^{\mathrm{aA}}$ & $3.67^{\mathrm{aA}}$ \\
\hline D4 & $4.67^{\mathrm{aA}}$ & $4.67 \mathrm{AB}$ & $4.33^{\mathrm{aAB}}$ & $3.00^{\mathrm{aB}}$ \\
\hline \multicolumn{5}{|c|}{ Kıvam (Kaşıkla) } \\
\hline $\mathrm{K}$ & $4.00^{\mathrm{bA}}$ & $3.67^{\mathrm{aA}}$ & $4.00^{\mathrm{aA}}$ & $3.33^{\mathrm{aA}}$ \\
\hline D1 & $4.67^{\mathrm{abA}}$ & $3.67^{\mathrm{aA}}$ & $4.00^{\mathrm{aA}}$ & $3.67^{\mathrm{aA}}$ \\
\hline D2 & $4.67^{\mathrm{abA}}$ & $4.67^{\mathrm{aA}}$ & $4.67^{\mathrm{aA}}$ & $4.00^{\mathrm{aA}}$ \\
\hline D3 & $5.00^{\mathrm{aA}}$ & $3.67^{\mathrm{aBC}}$ & $4.33^{\mathrm{aAB}}$ & $3.33^{\mathrm{ac}}$ \\
\hline D4 & $4.67^{\mathrm{abA}}$ & $4.00^{\mathrm{aA}}$ & $4.33^{\mathrm{aA}}$ & $2.67^{\mathrm{aB}}$ \\
\hline \multicolumn{5}{|c|}{ Kıvam (Ağızda) } \\
\hline K & $4.00^{\mathrm{aA}}$ & $3.67^{\mathrm{aA}}$ & $4.00^{\mathrm{aA}}$ & $3.33^{\mathrm{aA}}$ \\
\hline D1 & $4.00^{\mathrm{aA}}$ & $3.67^{\mathrm{aA}}$ & $3.67^{\mathrm{aA}}$ & $3.67^{\mathrm{aA}}$ \\
\hline D2 & $4.33^{\mathrm{aA}}$ & $4.00^{\mathrm{aA}}$ & $4.00^{\mathrm{aA}}$ & $4.00^{\mathrm{aA}}$ \\
\hline D3 & $4.00^{\mathrm{aA}}$ & $3.67^{\mathrm{aA}}$ & $4.33^{\mathrm{aA}}$ & $3.33^{\mathrm{aA}}$ \\
\hline D4 & $4.33^{\mathrm{aA}}$ & $3.33^{\mathrm{aA}}$ & $4.00^{\mathrm{aA}}$ & $3.33^{\mathrm{aA}}$ \\
\hline \multicolumn{5}{|l|}{ Koku } \\
\hline $\mathbf{K}$ & $4.33^{\mathrm{aAB}}$ & $4.33^{\mathrm{aAB}}$ & $5.00^{\mathrm{aA}}$ & $3.67^{\mathrm{aB}}$ \\
\hline D1 & $4.33^{\mathrm{aA}}$ & $4.00^{\mathrm{aA}}$ & $3.67^{\mathrm{bA}}$ & $3.67^{\mathrm{aA}}$ \\
\hline D2 & $4.67^{\mathrm{aA}}$ & $3.67^{\mathrm{aAB}}$ & $3.67^{\mathrm{bAB}}$ & $3.00^{\mathrm{aB}}$ \\
\hline D3 & $4.00^{\mathrm{aA}}$ & $3.33^{a A B}$ & $3.67^{\mathrm{bA}}$ & $2.67^{\mathrm{aB}}$ \\
\hline D4 & $3.67^{\mathrm{aA}}$ & $3.67^{a A}$ & $3.67^{\mathrm{bA}}$ & $3.33^{\mathrm{aA}}$ \\
\hline \multicolumn{5}{|l|}{ Tat } \\
\hline $\mathbf{K}$ & $4.00^{\mathrm{aA}}$ & $4.00^{\mathrm{aA}}$ & $3.33^{\mathrm{aB}}$ & $3.00^{\mathrm{aB}}$ \\
\hline D1 & $4.00^{\mathrm{aA}}$ & $3.67^{\mathrm{aA}}$ & $3.33^{\mathrm{aA}}$ & $2.00^{\mathrm{bA}}$ \\
\hline D2 & $3.33^{\mathrm{aA}}$ & $4.00^{\mathrm{aA}}$ & $3.67^{\mathrm{aA}}$ & $2.67^{\mathrm{abA}}$ \\
\hline D3 & $3.00^{\mathrm{aA}}$ & $3.33^{\mathrm{aA}}$ & $3.33^{\mathrm{aA}}$ & $2.67^{\mathrm{abA}}$ \\
\hline D4 & $3.33^{\mathrm{aA}}$ & $3.67^{\mathrm{aA}}$ & $3.00^{\mathrm{aA}}$ & $3.00^{\mathrm{aA}}$ \\
\hline
\end{tabular}

$a-b(\downarrow)$ Test edilen her parametre için (dış görünüş, kıvam kaşıkla, kıvam ağızda, koku, tat) aynı harfleri taşıyan ortalamalar arasındaki fark istatistiksel olarak önemli değil$\operatorname{dir}(p>0.05)$. $\mathrm{A}(\rightarrow)$ Aynı harfleri taşıyan ortalamalar arasındaki fark istatistiksel olarak önemli değildir $(p>0.05)$.

\section{SONUÇ}

Tüm gruplarda depolamanın 14. gününden sonra duyusal özellik puanlarının azalmasına bağlı olarak, üretilen AV'li yoğurtlarda 14 gün depolamanın uygun olduğu belirlenmiştir. Fizikokimyasal analiz sonuçları genel olarak değerlendirildiğinde probiyotik yoğurda AV jeli suyu ilavesi ile yoğurdun probiyotik bakteriler için taşıyıcı olarak kullanılabileceği ve \%1 ile 5 arasında AV jeli suyu ilavesinin probiyotik yoğurt üretiminde başarıyla kullanılabileceği ortaya konmuştur. AV yapısından bulunan $A, C, E$, B1 (tiyamin), B2 (riboflavin), B3 (niyasin), B12 (kobalamin) vitaminleri, mineraller, amino asitler ve enzimler içeren yapısıyla önemli bir bitkidir ve tıbbi değeri nedeniyle binlerce yıldır kullanılmaktadır. Son yıllarda AV ila- veli fonksiyonel gıdaların tüketimine olan talebin artmasıyla, AV ilaveli ürünlerin üretimi açısından yeni araştırma planlanması önemlidir.

\section{TEŞEKKÜR}

Bu çalışma 2019 yılı TÜBiTAK 2209-B Sanayi Odaklı Lisans Bitirme Tezi Programı tarafından desteklenmiştir. TÜBITAK'a ve Yörükoğlu Süt ve Ürünleri San. Tic. A.Ş.'ye teşekkür ederiz.

\section{KAYNAKLAR}

Anonim. (2002). Çiğ süt Standardı, Türk Standartları Enstitüsü, Ankara.

Anonim. (2006). Yoğurt Standardı. TS 1330. Türk Standartlar Enstitüsü, Ankara. 
Başyiğit, G., Kuleaşan, H., Karahan, A.G. (2006). Viability of human derived probiotic lactobacilli in ice-cream produced with sucrose and aspartame. Journal of Industrial Microbiology and Biotechnology, 33: 796-800.

Başyiğit, G., 2004. Bazı Laktik Asit Bakterilerinin Probiyotik Olarak Kullanılma Özellikleri. Yüksek Lisans Tezi, Süleyman Demirel Üniversitesi Fen Bilimleri Enstitüsü, 96 s, Isparta

Başyiğit Kılıç, G., Kuleaşan, H., Eralp, I., Karahan, A.G. (2009). Manufacture of Turkish Beyaz cheese added with probiotic strains. LWT - Food Science and Technology, 42: 10031008.

Başyiğit Kılıç, G., Karahan, A.G. (2010). Identification of lactic acid bacteria isolated from the fecal samples of healthy humans and patients with dyspepsia and determination of their $\mathrm{pH}$, bile and antibiotic tolerance properties. Journal of Molecular Microbiology and Biotechnology, 18: 220-229.

Başyiğit Kılıç, G., Kuleaşan, H., Sömer, V.F., Akpınar, D. (2013). Determination of potential probiotic properties of human originated Lactobacillus plantarum strains. Biotechnology and Bioprocess Engineering, 18: 479-485.

Başyiğit Kılıç, G., Akpınar, D. (2013). The effects of different levels of $\beta$-glucan on yoghurt manufactured with Lactobacillus plantarum strains as adjunct culture. Journal of Food, Agriculture \& Environment, 11(1): 281-287.

Başyiğit Kılıç, G., Akpınar, D. (2016). Assessment of technological characteristics of non-fat yoghurt manufactured with prebiotics and probiotic strains. Journal of Food Science and Technology, 53(1): 864-871.

Başyiğit Kılıç, G., Bilecen Şen, D., Alnakdalı, D., Gülşen, M. (2020). Aloe vera'nın gıda endüstrisinde kullanımı. Mühendislik Bilimleri ve Tasarım Dergisi/Journal of Engineering Sciences and Design, 8(1): 326-332.

Çelikel, A., Göncü, B., Akın, M.B., Akın, M.S. (2018). Süt ürünlerinde probiyotik bakterilerin canlılığını etkileyen faktörler. Batman Üniversitesi Yaşam Bilimleri Dergisi, 8(1/2): 59-68.

Çete, S., Arslan, F., Yaşar, A. (2005). Investigation of antimicrobial effects against some microorganisms of Aloe vera and Nerium oleander also examination of the effects on the xanthine oxidase activity in liver tissue treated with cyclosporin. Gazi University Journal of Science, 18(3): 375-380.

Deveci, H.A., Nur, G., Kırpık, M., Harmankaya, A., Yıldız, Y. (2016). Fenolik bileşik içeren bitkisel antioksidanlar. Kafkas Üniversitesi, Fen Bilimleri Enstitüsü Dergisi, 9(1): 26-32.

El-Sayed, S.M., El-Sayed, H.S. (2020). Production of UF-soft cheese using probiotic bacteria and Aloe vera pulp as a good source of nutrients. Annals of Agricultural Sciences, 65(1): 13-20.

Halkman, A.K. (2005). Gıda Mikrobiyolojisi Uygulamaları, Merck, Ankara.

Hamman, J.H. (2008). Composition and applications of Aloe vera leaf gel. Molecules, 13(8): 1599-1616.

Hussain, S.A., Patil, G.R., Yadav, V., Singh, R.R.B. (2015). Effect of storage on sensory quality, $\mathrm{pH}$, wheying-off and probiotic count of lassi supplemented with Aloe barbadensis Miller juice. Indian Journal of Dairy Science, 68(2): 105.

Ikram, A., Qasim Raza, S., Saeed, F., Afzaal, M., Munir, H., Ahmed, A.,Zahid, M., Muhammad Anjum, F. (2021). Effect of adding Aloe vera jell on the quality and sensory properties of yogurt. Food Science \& Nutrition, 9(1): 480-488.
Işıdan, H. (2009). Probiyotikler. Aquaculture Studies, 9(1): 009-010.

Javed, S. (2014). Aloe vera gel in food, health products, and cosmetics industry. In Studies in Natural Products Chemistry, 41: 261-285.

Karami, M. (2018). The effect of zinc and vitamin B12 together with thyme and Aloe vera extracts on the viability of Lactobacillus acidophilus $\mathrm{LA}-5 \otimes$ and physicochemical properties of Iranian yoghurt drink (Doogh). International Journal of Dairy Technology, 71: 149-156.

Karami, M.,Khodakarami, M. (2019). Evaluation of the effects of Aloe vera extract on chemical and microbial properties of low fat stirred probiotic yoghurt. Food Science and Technology, 16(94): 127-138.

Kaur, S., Kaur, H.P., Gupta, P. (2015). Physico-chemical analysis of Aloe vera fortified probiotic yoghurt. Internatınal Journal of Advances in Pharmacy, Biology and Chemistry, 4(2): 501-508.

Karahan, A.G., Arıdoğan-Cicioğlu, B., Çakmakçı, M.L. (2002). Genel Mikrobiyoloji Uygulama Kılavuzu. SDÜ Yayın No. 24: $171 \mathrm{~s}$.

Kaya, H.I. (2013). Tarhana izolatı bazı laktik asit bakterilerinin bakteriyosinleri ve fermantasyonda patojen bakteriler üzerine etkisi. Master Tezi, Pamukkale Üniversitesi, Fen Bilimleri Enstitüsü, Denizli, Türkiye.

Keogh, M.K., O’Kennedy, B.T. (199)8. Rheology of stirred yogurt as affected by added milk fat, protein and hydrocolloids. Journal of Food Science, 63(1): 108-112.

Mahmoudi, R., Bajalanlou, F., Ghajarbeygi, P., Pakbin, B. (2016). Chemical properties and sensory evaluation of probiotic yoghurt manufactured with aqueous extract of Aloe vera. Journal of Biology and Today's World, 5(11): 197202.

Mendoza Mencia, J.M. (2018). Functional Plain Yogurt Enhanced with Inulin and Aloe Vera. Master of Science, School of Animal Sciences, Louisiana State University and Agricultural and Mechanical College.

Mokoena, M.P. (2017). Lactic acid bacteria and their bacteriocins: Classification, biosynthesis and applications against uropathogens: A mini-review. Molecules, 22(8): 1255.

Muhtekar, A., Desale, R.J., Bhosale, S. (2018). Effect of sensory and microbial properties of yogurt fortified with Aloe vera. The Pharma Innovation Journal, 7(10):146-14.

Niko, N., Ghajarbeygi, P., Mahmoudi, R., Mousavi, S., Mardani, K. (2016). Inhibitory effects of Aloe vera gel aqueous extract and $L$. casei against $E$. coli in yoghurt. Journal of Biology and Today's World, 5(9): 157-162.

Oğan, Y., Sezgin Ceyhun, E. (2019). Katkı maddesi antioksidanların gastronomi açısından değerlendirilmesi. Artvin International Congress on Social Sciences (AICOSS 19), 1719.

Omak, G., Özcan, T., \& Ersan, L. Y. (2016). Biyolojik Detoksifikasyon ve Probiyotikler. Uludağ Üniversitesi Ziraat Fakültesi Dergisi, 30(1): 157-168.

Özçelik, S., 1998. Gıda Mikrobiyolojisi Uygulama Kılavuzu. Süleyman Demirel Üniversitesi Ziraat Fakültesi Yayın No:7, Ders Kitapları No:7, Isparta.

Panesar,P.S., Shinde , C. (2012). Effect of storage on syneresis, $\mathrm{pH}$, Lactobacillus acidophilus count, Bifidobacterium bifidum count of Aloe vera fortified probiotic yoghurt. Current Research in Dairy Sciences, 4(1): 17-23. 
Aloe Vera Jel İçeceği İle Zenginleştilmiş Probiyotik Yoğurt Üretimi

Surjushe, A., Vasani, R., Saple, D.G. (2008). Aloe vera: a short review. Indian Journal of Dermatology, 53(4): 163.

Tekin, F., Şahin, O.Z., Karasu, Z., Nart, D., Özütemiz, Ö., Ersöz, G., Batur,Y., İlter, T. (2006). Aloe veraya bağlı ciddi toksik hepatit: Olgu sunumu. Akademik Gastroenteroloji Dergisi, 5(2): 134-136.

Todorov, S.D., Stojanovski, S., lliev, I., Moncheva, P., Nero, L.A., Ivanova, I.V. (2017). Technology and safety assessment for lactic acid bacteria isolated from traditional bulgarian fermented meat product "lukanka". Brazilian Journal of Microbiology, 48(3): 576-586.

Uymaz, B. (2010). Probiyotikler ve kullanım alanları. Pamukkale Üniversitesi Mühendislik Bilimleri Dergisi, 16(1): 95104.

Üçüncü, M. (2005). Süt ve Mamülleri Teknolojisi. Meta Basım, İzmir. 434-435.
Xiong, T., Guan, Q., Song, S., Hao, M., Xie, M. (2012). Dynamic changes of lactic acid bacteria flora during chinese sauerkraut fermentation. Food Control, 26(1): 178-181.

Yadav, A.K., Singh, A., Yadav, K.C. (2018). Efficacy of flavored Aloe vera cubes in probiotic yoğurt. Journal of Pharmacognosy and Phytochemistry, 7(4): 1609-1614.

Yeganehzad, S., Mzaheri-Tehrani, M., Shahidi, F. (2007). Studying microbial, physiochemical and sensory properties of directly concentrated probiotic yoghurt. African Journal of Agricultural Research, 2(8), 366-369.

Yılmaz, L. (2006). Yoğurt benzeri fermente süt ürünleri üretiminde farklı probiyotik kültür kombinasyonlarının kullanımı, Doktora Tezi, Uludağ Üniversitesi, Fen Bilimleri Enstitüsü, Bursa, Türkiye. 